\title{
A high-fructose diet induces changes in pp185 phosphorylation in muscle and liver of rats
}

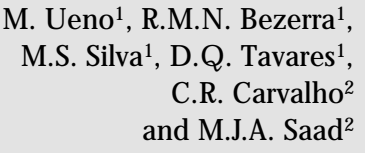

M. U eno ${ }^{1}$, R.M.N. Bezerra ${ }^{1}$,

M.S. Silva ${ }^{1}$, D.Q. Tavares ${ }^{1}$,

C.R. Carvalho ${ }^{2}$

and M.J.A. Saad ${ }^{2}$

\author{
${ }^{1}$ Departamento de Planejamento Alimentar e Nutrição, \\ Faculdade de Engenharia de Alimentos, and \\ ${ }^{2}$ Departamento de Clínica M édica, Faculdade de Ciências Médicas, \\ Universidade Estadual de Campinas, Campinas, SP, Brasil
}

\section{Correspondence}

M.J.A. Saad

Departamento de Clínica Médica FCM, UNICAMP

13081-970 Campinas, SP

Brasil

Fax: + 55-19-239-3114

E-mail: msaad@ head.fcm.unicamp.br

Research supported by FAPESP and $\mathrm{CNPq}$.

Received November 30, 1999 Accepted September 13, 2000

\section{Abstract}

Insulin stimulates the tyrosine kinase activity of its receptor resulting in the tyrosine phosphorylation of pp185, which contains insulin receptor substrates IRS-1 and IRS-2. These early steps in insulin action are essential for the metabolic effects of insulin. Feeding animals a high-fructose diet results in insulin resistance. However, the exact molecular mechanism underlying this effect is unknown. In the present study, we determined the levels and phosphorylation status of the insulin receptor and pp185 (IRS-1/2) in liver and muscle of rats submitted to a high-fructose diet evaluated by immunoblotting with specific antibodies. Feeding fructose (28 days) induced a discrete insulin resistance, as demonstrated by the insulin tolerance test. Plasma glucose and serum insulin and cholesterol levels of the two groups of rats, fructose-fed and control, were similar, whereas plasma triacylglycerol concentration was significantly increased in the rats submitted to the fructose diet $(\mathrm{P}<0.05)$. There were no changes in insulin receptor concentration in the liver or muscle of either group. However, insulin-stimulated receptor autophosphorylation was reduced to $72 \pm$ $4 \%(\mathrm{P}<0.05)$ in the liver of high-fructose rats. The IRS- 1 protein levels were similar in both liver and muscle of the two groups of rats. In contrast, there was a significant decrease in insulin-induced pp185 (IRS-1/2) phosphorylation, to $83 \pm 5 \%(\mathrm{P}<0.05)$ in liver and to $77 \pm$ $4 \%(\mathrm{P}<0.05)$ in muscle of the high-fructose rats. These data suggest that changes in the early steps of insulin signal transduction may have an important role in the insulin resistance induced by high-fructose feeding.
Insulin secretion tightly regulates glucose homeostasis by stimulating the peripheral use of glucose and inhibiting hepatic glucose output. The insulin receptor $ß$-subunit, which contains an intrinsic tyrosine kinase, undergoes tyrosyl autophosphorylation and is acti-

\section{Key words}

- Fructose

- Insulin receptor

- pp185 Phosphorylation vated in response to insulin binding to the extracellular $\alpha$-subunit (1). Subsequent steps in the insulin signal transduction are mediated via phosphorylation of specific intracellular proteins. Using antiphosphotyrosine antibodies an insulin-stimulated phospho- 
protein called pp185 was identified in many cells and tissues (2). One component of pp185, designated insulin receptor substrate 1 (IRS-1), was purified and its cDNA from several sources cloned (3). More recently another constituent of pp185 termed IRS-2 was also purified and its cDNA sequence determined (4). The tyrosine phosphorylated pp185 (IRS-1 and IRS-2) binds to various effector molecules including the regulatory subunit of phosphoinositol (PI) 3-kinase via src homology 2 domains (1). Recruitment of the catalytic subunit results in activation of PI 3-kinase, which is necessary for insulin action on glucose transport, glycogen synthesis, protein synthesis, anti-lipolysis, and suppression of hepatic gluconeogenesis by regulation of phosphoenolpyruvate carboxykinase (PEPCK) gene expression (5).

Impairment of insulin action (insulin resistance) is involved in many diseases such as non-insulin-dependent diabetes mellitus, obesity, hypertension, and cardiovascular disease (6). High-fructose rats are considered to be an animal model of insulin resistance associated with hyperinsulinemia, hypertriglyceridemia $(7,8)$ and hypertension (9). Although it has been shown that a highfructose diet alters the activity of several enzymes regulating hepatic carbohydrate metabolism, leading to hepatic insulin resistance $(10,11)$, the mechanisms by which excess fructose produces these effects are unknown. The role of the phosphorylation of insulin receptors and pp185 in vivo has not yet been examined in insulin resistance induced by a high-fructose diet. In the present study, we investigated the levels and phosphorylation status of the insulin receptor and pp185 in the liver and muscle of Wistar rats submitted to a high-fructose diet.

Male Wistar-Hannover rats 5 weeks old and weighing approximately $120 \mathrm{~g}$ were randomly divided into two diet groups (control and high-fructose) for 28 days. The control diet was standard rodent chow (NuvilabNuvital, Curitiba, PR, Brazil) containing (\% calories) $64 \%$ vegetable starch, $9.5 \%$ fat as vegetable oil, and $26.5 \%$ animal protein (beef and fish flours). The high-fructose diet contained (\% calories) $66 \%$ fructose, $12 \%$ fat as vegetable oil, and $22 \%$ animal protein (casein). The mineral and vitamin mix used in the experimental diet met the criteria specified by the American Institute of Nutrition AIN93 (12). The rats were maintained under standard conditions $\left(20-22^{\circ} \mathrm{C}\right.$ and a $12-\mathrm{h}$ light/dark cycle) with free access to food and tap water, and were weighed weekly in order to record their body weight gain.

For characterization of this animal model, after a 6-h fast, the fructose- and standard chow-fed rats were anesthetized with sodium thiopental $(80 \mathrm{mg} / \mathrm{kg}$ body weight, ip) and blood samples were collected by cardiac puncture. After centrifugation, the serum was utilized for the determination of triacylglycerol and cholesterol concentration by the enzymatic method using Labtest Diagnostica kits (Lagoa Santa, MG, Brazil), and of insulin concentration by double-antibody radioimmunoassay using a specific rat kit from Diagnostic Products Corp. (Los Angeles, CA, USA). The effect of fructose feeding on the ability of insulin to stimulate glucose disposal was estimated by the intravenous insulin tolerance test. After a 14-h fast, the animals were anesthetized with sodium thiopental ( $80 \mathrm{mg} / \mathrm{kg}$ body weight) and tail blood samples were drawn before, and at 0 (basal), 4, 8, 12, and 16 min after insulin injection $(60 \mu \mathrm{g})$ for the determination of glucose levels using an enzymatic method and a Labtest Diagnostica kit. The rate constant for plasma glucose disappearance (Kitt) was calculated using the formula $0.693 / t_{1 / 2}$. The plasma glucose $t_{1 / 2}$ was calculated by the slope of the least square analysis of the plasma glucose concentration during the linear decay phase (13).

At the end of the 4-week diet period, the rats were anesthetized with sodium thiopental $(80 \mathrm{mg} / \mathrm{kg}$ body weight, ip) and used in the experiments as soon as the loss of foot 
and corneal reflexes were assured. The abdominal cavity was opened, the portal vein exposed, and $60 \mu \mathrm{g}$ insulin was injected. Within $30 \mathrm{~s}$, the liver was removed, minced coarsely and immediately homogenized in 10 volumes of solubilization buffer $\mathrm{A}, \mathrm{pH}$ 7.4 ( $1 \%$ sodium dodecyl sulfate (SDS), 100 $\mathrm{mmol} / \mathrm{l}$ tris[hydroxymethyl]aminomethane (Tris), $\mathrm{pH} 7.4,10 \mathrm{mmol} / 1$ sodium pyrophosphate, $100 \mathrm{mmol} / 1$ sodium fluoride, 10 $\mathrm{mmol} / \mathrm{l}$ ethylenediaminetetraacetic acid, and $10 \mathrm{mmol} / \mathrm{l}$ sodium vanadate) in a water bath maintained at $100^{\circ} \mathrm{C}$, using a polytron PTA 20S generator (model PT 10/35, Brinkmann Instruments, Westbury, NY, USA) operated at maximum speed for $20 \mathrm{~s}$. The homogenate was boiled for $10 \mathrm{~min}$ and then cooled in an ice bath for $40 \mathrm{~min}$. Approximately $90 \mathrm{~s}$ after insulin injection, hindlimb muscle samples were excised and homogenized as described above. The tissue extracts were centrifuged at $16,000 \mathrm{~g}$ at $4^{\circ} \mathrm{C}$ for $20 \mathrm{~min}$, and the supernatant was used as the sample. In some experiments, the tissues were extracted at $4^{\circ} \mathrm{C}$ with homogenization buffer B (same as buffer A except that $1 \%$ Triton X-100 replaced $1 \%$ SDS and $2 \mathrm{mmol}$ phenylmethylsulfonyl fluoride and $0.1 \mathrm{mg} / \mathrm{ml}$ aprotinin was added) and the supernatant was used for immunoprecipitation with anti-insulin receptor antibody and protein A-Sepharose $6 \mathrm{MB}$. The samples were treated with Laemmli buffer containing $100 \mathrm{mmol} / \mathrm{l}$ dithiothreitol and heated in a boiling water bath for $4 \mathrm{~min}$. For total extracts, aliquots of samples containing $200 \mu \mathrm{g}$ of protein were submitted to $6 \%$ SDS-polyacrylamide gel electrophoresis (SDS-PAGE). Electrotransfer of proteins from the gel to the nitrocellulose membrane was performed for $90 \mathrm{~min}$ at $120 \mathrm{~V}$ (constant) in a BioRad miniature transfer apparatus (Mini-Protean). The nonspecific protein binding was reduced by preincubating the filter for $2 \mathrm{~h}$ at $22^{\circ} \mathrm{C}$ in blocking buffer, $\mathrm{pH}$ 7.4 (5\% nonfat dry milk, $10 \mathrm{mmol} / \mathrm{l}$ Tris, 150 $\mathrm{mmol} / \mathrm{l} \mathrm{NaCl}$, and $0.02 \%$ Tween 20 ). The nitrocellulose blot was incubated for $4 \mathrm{~h}$ at $22^{\circ} \mathrm{C}$ with antiphosphotyrosine antibody, anti-insulin receptor antibody (anti-IR) or anti-IRS-1 antibody diluted in blocking buffer, pH 7.4 (3\% nonfat dry milk, $10 \mathrm{mmol} / \mathrm{l}$ Tris, $150 \mathrm{mmol} / \mathrm{l} \mathrm{NaCl}$, and $0.02 \%$ Tween 20). Antibodies were from Santa Cruz Biotechnology (Santa Cruz, CA, USA). The blots were incubated with $2 \mu \mathrm{Ci}$ of $\left[{ }^{125} \mathrm{I}\right]-$ protein $\mathrm{A}(30 \mu \mathrm{Ci} / \mu \mathrm{g})$ in $10 \mathrm{ml}$ of blocking buffer $\left(1 \%\right.$ nonfat dry milk) for $1 \mathrm{~h}$ at $22^{\circ} \mathrm{C}$ and washed again as described above. $\left[{ }^{125} \mathrm{I}\right]-$ Protein A bound to antibodies was detected by autoradiography using preflashed Kodak XAR film with a Cronex Lightning Plus intensifying screen at $-80^{\circ} \mathrm{C}$ for $12-48 \mathrm{~h}$. Band intensities were quantitated by optical densitometry (model GS 300; Hoefer Scientific Instruments, San Francisco, CA, USA) of the developed autoradiographs that were used at exposures in the linear range.

Experiments were always performed by analyzing samples from the fructose-fed rats parallel to the control group. Different groups of rats were used for tissue sampling and for the biochemical assays. The unpaired Student $t$-test was used for comparisons and the significance level was $\mathrm{P}<0.05$.

At the end of the 4-week experimental period there were no significant differences between control and fructose-fed rats in total body weight, or in the basal serum glucose, cholesterol and insulin concentration. However, the serum triacylglycerol concentration was significantly higher in the group eating fructose than in the control (fructose: $219 \pm 31$ vs control: $128 \pm 9 \mathrm{mg} / \mathrm{dl}$ ). In order to demonstrate that the fructose-fed rats were insulin resistant, the animals from both groups were submitted to an insulin tolerance test. The glucose disappearance rate (Kitt) during this test was significantly lower in fructosefed than in control rats, thus demonstrating a moderate state of insulin resistance (Table $1)$.

Insulin receptor and IRS-1 protein levels (Figure 1a and $\mathrm{b}$ ) did not change in the liver of fructose-fed rats compared to controls, as 
determined by immunoblotting with anti-IR and anti-IRS-1 antibodies. However, after stimulation with insulin, in samples previously immunoprecipitated with anti-IR antibody and immunoblotted with antiphosphotyrosine antibody there was a clear decrease in insulin-stimulated receptor autophosphorylation to $72 \pm 4 \%$ in fructose-fed animals compared to controls $(\mathrm{P}<0.05$; Figure $1 \mathrm{c})$. In anti-phosphotyrosine blots of whole tissue extracts, a broad protein band migrating between 165 and $185 \mathrm{kDa}$ was detectable after insulin stimulation (Figure 1d). This band is known as pp185 and contains IRS- 1 and IRS-2 (4). The phosphorylation of pp185 in the fructose-fed group was reduced to $83 \pm$ $5 \%(\mathrm{P}<0.05)$ compared to control. As observed for the liver, the fructose diet produced no change in insulin receptor or IRS1 protein levels in rat skeletal muscle (Figure $2 \mathrm{a}$ and $\mathrm{b}$ ). In contrast to the results observed in the liver, following stimulation with insulin, phosphorylation of the insulin receptor did not change in the fructose-fed rats compared to control (Figure 2c). However, there was a decrease to $76 \pm 5 \%(\mathrm{P}<0.05)$ in $\mathrm{pp} 185$ phosphorylation in muscle of fructose-fed rats compared to control (Figure 2d).

The insulin resistance described in an animal model involving a high-fructose diet is associated with glucose intolerance, increased serum triacylglycerol and insulin concentration and decreased insulin sensitivity $(7-9,11)$. Our results showed a moderate insulin resistance state in the fructosefed animals, demonstrated by a decreased glucose disappearance rate after insulin infusion, and an increase in plasma triacylglycerol concentration. The discrepancies in the degree of insulin resistance and in the metabolic parameters (plasma glucose and serum insulin levels) of our study compared to previous reports may be related to the duration of fructose feeding and to the lipid content and type of the diets $(7,8)$.

Despite the normal number of insulin receptors in the liver and muscle of fructosefed rats, there was a reduction in insulin receptor autophosphorylation in the liver after insulin stimulation in vivo. The reduction observed in our study may be of biological significance, since a decrease in receptor phosphorylation has been correlated with insulin resistance in different animal models $(14,15)$. The results of the present study demonstrated that there is a significant decrease in the level of hepatic and muscle pp185 (IRS-1/IRS-2) tyrosine phosphorylation. A decreased insulin ability to suppress hepatic glucose production has been implicated as one of the elements of insulin resistance in this model $(7,8)$. The IRS- 1 or IRS2/PI 3-kinase association induced by insulin is necessary and in some cases sufficient to elicit many of the insulin effects on glucose metabolism in liver and muscle (16). The PEPCK is a regulatory enzyme for gluconeogenesis. Recent reports demonstrated that inhibitors of PI 3-kinase are able to block the effects of insulin on PEPCK gene transcription in liver cells (5), suggesting that the control of insulin over PEPCK is mediated

Table 1 - Body weight, insulin tolerance test, fasting plasma glucose, insulin, triacylglycerol and cholesterol after 4 weeks of dietary manipulation.

The results are reported as the mean \pm SEM. The number of animals in each group is shown in parentheses. $*^{*} \mathrm{P}<0.05$ vs control group (unpaired Student t-test).

\begin{tabular}{lcccccc}
\hline & $\begin{array}{c}\text { Weight } \\
(\mathrm{g})\end{array}$ & \multicolumn{1}{c}{$\begin{array}{c}\text { Kitt } \\
(\% / \mathrm{min})\end{array}$} & $\begin{array}{c}\text { Glucose } \\
(\mathrm{mg} / \mathrm{dl})\end{array}$ & $\begin{array}{c}\text { Insulin } \\
(\mu \mathrm{U} / \mathrm{ml})\end{array}$ & $\begin{array}{c}\text { Triacylglycerol } \\
(\mathrm{mg} / \mathrm{dl})\end{array}$ & $\begin{array}{c}\text { Cholesterol } \\
(\mathrm{mg} / \mathrm{dl})\end{array}$ \\
\hline Control & $271 \pm 6(40)$ & $3.9 \pm 0.3(14)$ & $76 \pm 3(23)$ & $44 \pm 4(13)$ & $128 \pm 9(11)$ & $65 \pm 2(13)$ \\
Fructose & $270 \pm 5(40)$ & $2.9 \pm 0.2^{*}(13)$ & $82 \pm 6(15)$ & $44 \pm 5(8)$ & $219 \pm 31^{*}(7)$ & $72 \pm 4(9)$
\end{tabular}


Figure 1 - Effects of a high-fructose diet on protein levels of insulin receptor (IR) (a) and IRS-1 (b), and tyrosine phosphorylation levels of IR (c) and pp185 (d) in rat liver. The proteins were isolated as described in Material and Methods. Aliquots with the same amount of protein were loaded onto 6\% SDS-polyacrylamide gel, transferred to a nitrocellulose membrane, and immunoblotted with anti-IR (a), anti-IRS-1 (b), and antiphosphotyrosine (d) antibodies. In some samples from control (C) animals not treated with insulin, control animals treated with insulin, fructose (F)-fed animals not treated with insulin and fructose-fed animals treated with insulin, the supernatants were immunoprecipitated with anti-IR and immunoblotted with antiphosphotyrosine (c). Figure 1d shows a broad band migrating between 115-130 kDa in phosphotyrosine blots of liver extracts. The changes in tyrosine phosphorylation levels of this band after insulin stimulation are not consistent and classically there is no insulin receptor substrate migrating in this band. A representative autoradiograph from six experiments is shown. Scanning densitometry was performed on autoradiograms to determine IR and IRS-1 concentrations for tyrosine phosphorylation of proteins. Values are reported as mean \pm SEM of six experiments. $* P<0.05$ vs control (unpaired Student t-test).

Figure 2 - Effects of a high-fructose diet on protein levels of insulin receptor (IR) (a) and IRS-1 (b), and tyrosine phosphorylation levels of IR (c) and pp185 (d) in rat muscle. The proteins were isolated as described in Material and Methods. Aliquots with the same amount of protein were loaded onto 6\% SDS-polyacrylamide gel, transferred to a nitrocellulose membrane, and immunoblotted with anti-IR (a), anti-IRS-1 (b), and antiphosphotyrosine (d) antibodies. In some samples from control (C) animals not treated with insulin, control animals treated with insulin, fructose (F)-fed animals not treated with insulin and fructose-fed animals treated with insulin, the supernatants were immunoprecipitated with anti-IR and immunoblotted with antiphosphotyrosine (c). A representative autoradiograph from six experiments is shown. Scanning densitometry was performed on autoradiograms to determine IR and IRS-1 concentrations for tyrosine phosphorylation of proteins. Values are reported as mean \pm SEM of six experiments. $* \mathrm{P}<0.05$ vs control (unpaired Student t-test).
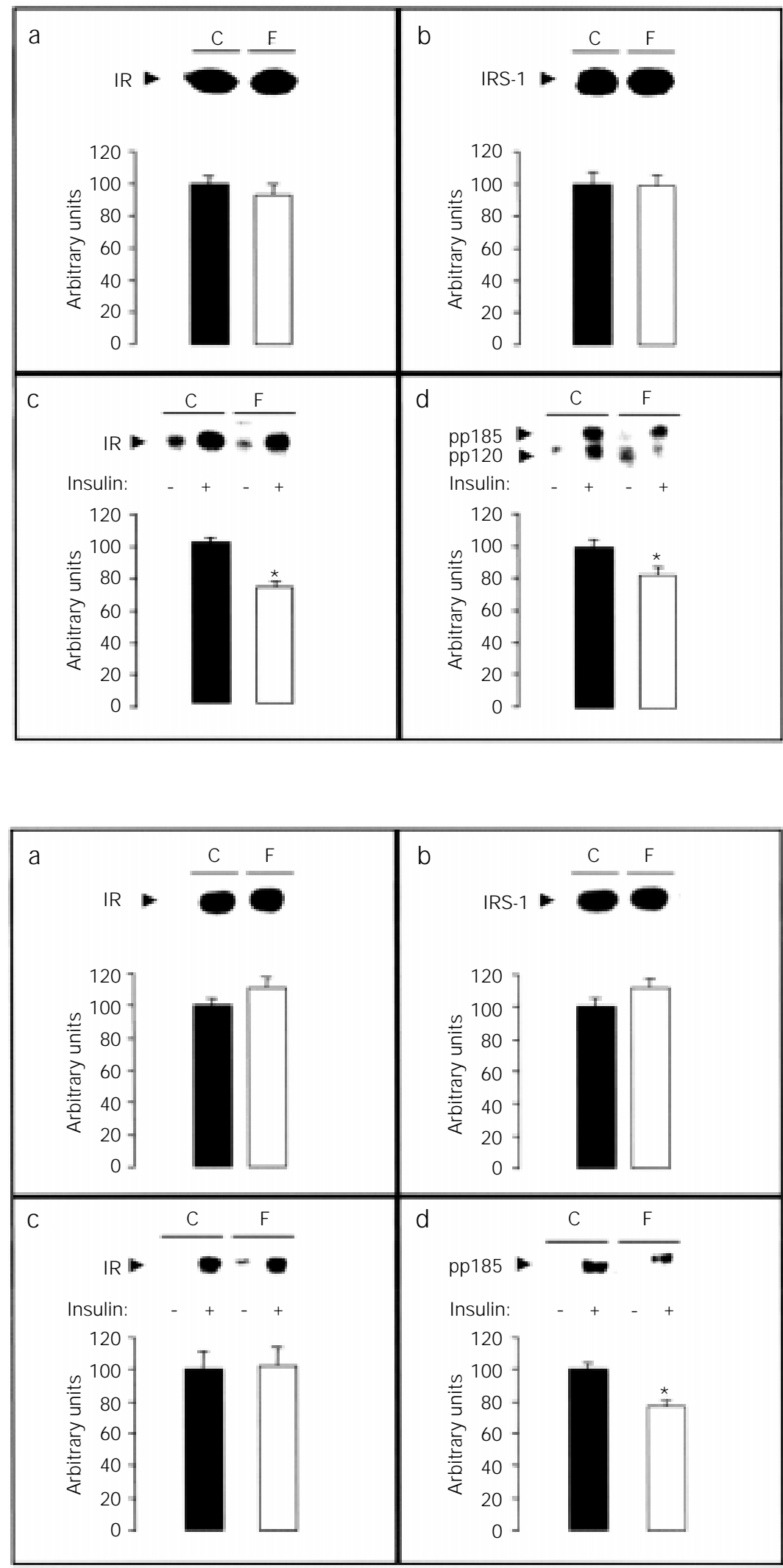
by pp 185 phosphorylation (IRS-1/IRS-2) and PI 3-kinase. There is a previous study demonstrating that PEPCK activity is increased in a high fructose-fed animal model (11). Taking these previous studies together with our results, we may speculate that the reduction in pp185 phosphorylation can induce changes in IRS-1 and IRS-2/PI 3-kinase association/activation in the liver of fructosefed rats, and this effect may have a role in the insulin resistance of this animal model.

Parallel to the reduced tyrosine phosphorylation level in the muscle of fructose-fed rats, pp185 showed a decreased electrophoretic mobility in SDS-PAGE. This reduced tyrosine phosphorylation may be due to the activation of tyrosine phosphatase(s) and/or to serine/threonine phosphorylation. IRS-1 and IRS-2 contain many potential serine/ threonine phosphorylation sites in motifs recognized by various kinases such as protein kinase $\mathrm{C}$ (PKC), and mitogen-activated protein kinases $(3,17)$. Serine phosphorylation may play a role in the regulation of IRS1 and IRS-2 signaling. It is known that increased phosphorylation of the insulin receptor and IRS-1 in serine and threonine residues reduces insulin-mediated receptor phosphorylation in tyrosine, and inhibits the insulin-dependent tyrosine kinase activity of the receptor (18). The enhanced synthesis of triacylglycerol observed in the high-fructose diet model is associated with the increase of 1,2-sn-diacylglycerol and the increased expression of one PKC isoenzyme in these rats (19). Thus, it is possible that an increase in PKC activity, probably by increasing serine phosphorylation of insulin receptors and pp185, may play a role in the alteration in tyrosine phosphorylation level of pp185 (IRS$1 /$ IRS-2) observed in this study. In agreement with this hypothesis, there was a decrease in electrophoretic mobility of pp 185 in muscle, probably related to an increase in serine/threonine phosphorylation of this band, as previously described (20).

In muscle, pp185 tyrosine phosphorylation and PI 3-kinase activation are essential steps in insulin-induced glucose transport (1). The decrease in insulin-induced pp185 tyrosine phosphorylation in muscle from fructose-fed rats observed by us may also contribute to the insulin resistance of this animal.

This study has shown that a reduction in the phosphorylation of pp 185 (IRS-1/IRS-2) in the liver and muscle of fructose-fed rats may contribute to explaining some aspects of insulin resistance in this animal model.

\section{Acknowledgments}

The authors wish to thank Vêpe Indústria Alimentícia Ltda. (São Bernardo do Campo, SP, Brazil) for kindly providing the fructose, and also Mr. L. Janeri, Ms. C. da Silva and Ms. Y. Fagnani for technical assistance.

\section{References}

1. White MF (1997). The insulin signaling system and the IRS proteins. Diabetologia, 40: S2-S17.

2. White MF, Maron R \& Kahn CR (1985). Insulin rapidly stimulates tyrosine phosphorylation of a $\mathrm{M}_{r}-185,000$ protein in intact cells. Nature, 318: 183-186.

3. Sun XJ , Rothenberg PA \& Kahn CR (1991). Structure of the insulin receptor substrate IRS-1 defines a unique signal transduction protein. Nature, 352: 73-77.

4. Sun XJ, Wang LM, Zhang Y, Yenush L, Myers J r MG, Glasheen EM, Lane WS,
Pierce JH \& White MF (1995). Role of IRS-2 in insulin and cytokine signaling. Nature, 377: 173-177.

5. Sutherland C, O'Brien RM \& Granner DK (1995). Phosphatidylinositol 3-kinase, but not p70/p85 ribosomal S6 protein kinase, is required for the regulation of phosphoenolpyruvate carboxykinase (PEPCK) gene expression by insulin. J ournal of Biological Chemistry, 270: 15501-15506.

6. O'Doherty R, Stein D \& Foley J (1997). Insulin resistance. Diabetologia, 40: B10B15.
7. Zavaroni I, Sander $S$, Scott $S \&$ Reaven GM (1980). Effect of fructose feeding on insulin secretion and insulin action in the rat. Metabolism, 29: 970-973.

8. Tobey TA, Mondon CE, Zavaroni I \& Reaven GM (1982). Mechanism of insulin resistance in fructose-fed rats. Metabolism, 31: 608-612.

9. Thorburn $A W$, Storlien $L H$, J enkins $A B$, Khouri S \& Kraegen EW (1989). Fructoseinduced in vivo insulin resistance and elevated plasma triglyceride levels in rats. American J ournal of Clinical Nutrition, 49: 
1155-1163.

10. Tuovinen CGR \& Bender AE (1975). Some metabolic effects of prolonged feeding of starch, sucrose, fructose and carbohydrate-free diet in the rat. Nutrition and Metabolism, 19: 161-172.

11. Blakely SR, Hallfrisch J , Reiser S \& Prather E (1981). Long-term effects of moderate fructose feeding on glucose tolerance parameters in rats. J ournal of Nutrition, 111: 307-314.

12. Reeves PG, Nielsen FH \& Fahey J r GC (1993). AIN-93 purified diets for laboratory rodents: report of the American Institute of Nutrition ad hoc writing committee on the reformulation of the AIN-76 rodent diet. J ournal of Nutrition, 123: 1939-1951.

13. Bonora E, Moghetti $\mathrm{P}$, Zancanaro $\mathrm{C}$, Cigolini M, Querena M, Cacciotori V, Corgnati A \& Muggeo M (1989). Estimates of in vivo insulin action in man: comparison of insulin tolerance tests with euglycemic and hyperglycemic glucose clamp studies. J ournal of Clinical Endocrinology and Metabolism, 68: 374-378.

14. Saad MJ A, Folli F, Kahn J \& Kahn CR (1993). Modulation of insulin receptor, insulin receptor substrate-1, and phosphatidylinositol 3-kinase in liver and muscle of dexamethasone-treated rats. J ournal of Clinical Investigation, 92: 2065-2072.

15. Carvalho CRO, Brenelli SL, Silva AC, Nunes ALB, Velloso LA \& Saad MJA (1996). Effect of aging on insulin receptor, insulin receptor substrate-1, and phosphatidylinositol 3-kinase in liver and muscle of rats. Endocrinology, 137: 151-159.

16. Shepherd PR, Withers DJ \& Siddle K (1998). Phosphoinositide 3-kinase: the key switch mechanism in insulin signalling. Biochemical J ournal, 333: 471-490.

17. Mothe I \& Obberghen EV (1996). Phosphorylation of insulin receptor substrate-1 on multiple serine residues, 612,632 , 662 , and 731 , modulates insulin action.
J ournal of Biological Chemistry, 271: 11222-11227.

18. Stadtmauer L \& Rosen OM (1986). Increasing the CAMP content of IM-9 cells alters the phosphorylation state and kinase activity of the insulin receptor. J ournal of Biological Chemistry, 261: 34023407.

19. Donnelly R, Reed M, Azhar $S \&$ Reaven GM (1994). Expression of the major isoenzyme of protein kinase-C in skeletal muscle, $\mathrm{nPKC} \theta$, varies with muscle type and in response to fructose-induced insulin resistance. Endocrinology, 135: 23692374.

20. Tanti J -F, Grémeaux T, Van Obberghen E \& Le Marchand-Brustel Y (1994). Serine/ threonine phosphorylation of insulin receptor substrate 1 modulates insulin receptor signalling. J ournal of Biological Chemistry, 269: 6051-6057. 